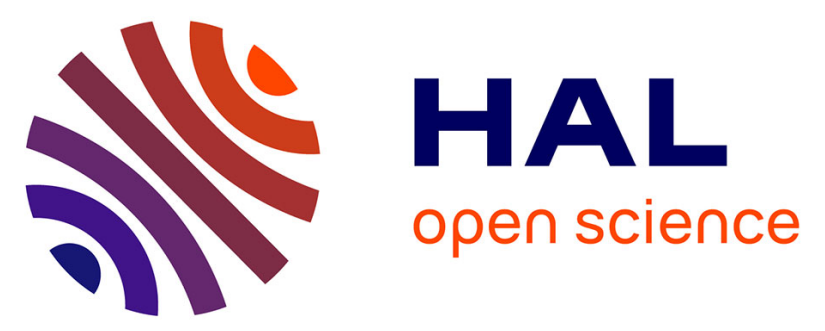

\title{
A Multi-criteria approach for choosing a new public transport system linked to urban development: a method developed in the Bahn.Ville project for a tram-train scenario in the Saint-Étienne region
}

Alain L'Hostis, Claude Soulas, Bogdan Vulturescu

\section{To cite this version:}

Alain L'Hostis, Claude Soulas, Bogdan Vulturescu. A Multi-criteria approach for choosing a new public transport system linked to urban development: a method developed in the Bahn.Ville project for a tram-train scenario in the Saint-Étienne region. RTS - Recherche Transports Sécurité, 2017, 2016 (01-02), pp.17-25. 10.4074/S0761898016002028 . hal-01670587

\author{
HAL Id: hal-01670587 \\ https://hal.science/hal-01670587
}

Submitted on 21 Dec 2017

HAL is a multi-disciplinary open access archive for the deposit and dissemination of scientific research documents, whether they are published or not. The documents may come from teaching and research institutions in France or abroad, or from public or private research centers.
L'archive ouverte pluridisciplinaire HAL, est destinée au dépôt et à la diffusion de documents scientifiques de niveau recherche, publiés ou non, émanant des établissements d'enseignement et de recherche français ou étrangers, des laboratoires publics ou privés. 


\title{
A Multi-criteria approach for choosing a new public transport system linked to urban development: a method developed in the Bahn.Ville project for a tram-train scenario in the Saint-Étienne region
}

\author{
Une approche multicritère pour le choix d'un nouveau système de transports pubics lié au \\ développement urbain : une méthode développée dans le projet Bahn.Ville pour un scénario \\ tram-train dans la région de Saint-Étienne
}

\author{
Alain L'Hostis · Claude Soulas · Bogdan Vulturescu \\ (C) IFSTTAR et Éditions NecPlus 2016
}

\begin{abstract}
Résumé Le succès du Transit Oriented Development (TOD) ou urbanisme ferroviaire dépend de plusieurs facteurs dont les caractéristiques du système de transport. Dans les projets de tram-train typiques, à l'exemple de celui de Karlsruhe, un nouveau système de transport est proposé par l'association d'un matériel roulant spécifique, intermédiaire entre tramway et train, et de la combinaison de voies urbaines de tramway et du réseau ferroviaire conventionnel existant. L'adaptation à la fois aux contextes centraux et périphériques, et la promesse d'investissements de relativement faible coût par la réutilisation d'infrastructures existantes, explique l'intérêt porté sur ces systèmes dans les contextes métropolitains. L'approche tram-train combine des considérations urbaines avec une prise en compte des caractéristiques fonctionnelles du système de transport, dans le but d'apporter des gains d'accessibilité supplémentaires, par comparaison avec des systèmes plus lourds. Nous proposons d'évaluer le projet de la conversion de la ligne ferroviaire régionale Fraisses-Firminy-Saint-Étienne en un corridor de tram-train. Ceci implique l'introduction d'un ensemble de nouveaux arrêts dont nous voulons évaluer la pertinence : à partir d'une liste donnée d'arrêts, lesquels devraient être réalisés en priorité ? Pour traiter cette question, nous avons conçu et mis en œuvre une approche
\end{abstract}

\footnotetext{
Alain L'Hostis $(\triangle)$

Université Paris-Est, Laboratoire Ville Mobilité Transport (LVMT UMR T 9403) Ifsttar, Ecole des Ponts ParisTech, UPEM 14-20,

Boulevard Newton - Cité Descartes - Champs sur Marne 77477

Marne la Vallée Cedex 2, France e-mail: alain.lhostis@ifsttar.fr

Claude Soulas $(\square)$

Ifsttar/Cosys/Grettia - Génie des Réseaux de Transport Terrestres et Informatique Avancée e-mail: claude.soulas@ifsttar.fr

Bogdan Vulturescu $(\square)$

SATIE, ENS Cachan 61, avenue du Président Wilson - 94235 Cachan

Cedex, France e-mail: bogdan.vulturescu@ifsttar.fr
}

multicritère associant transport et urbanisme. Les critères incluent la mesure de l'accessibilité, l'impact de chaque arrêt sur le temps total de transport, la mesure du nombre d'emplois et de population concernés, le recensement des fonctions urbaines existantes, la mesure du potentiel de développement urbain autour de l'arrêt, le potentiel de connexion avec les autres modes et enfin le coût de réalisation.

Mots clés méthodes $\cdot$ multicritères $\cdot$ tram-train $\cdot$ TOD

Abstract The success of Transit Oriented Development (TOD) or rail oriented development depends on several factors, among them the characteristics of the public transport system should not be neglected. In the typical tram-train approaches as exemplified in the Karlsruhe experience, a new transport systems is proposed from the association of specific rolling stock, intermediate between tramways and trains, to a combination of urban tram tracks and existing conventional railway system. The adaptation to both central and peripheral contexts, and the promise of relatively low investment costs by reusing the existing infrastructure, explain the interest of such systems in metropolitan contexts. The tram-train approach combines urban considerations with functional characteristics of the transport system in order to provide new benefits in terms of accessibility, as compared to heavier systems.

We propose to examine the project of the conversion of the regional rail Fraisses-Firminy-Saint-Étienne line into a tram-train corridor. This involves the introduction of a series of new stops that we want to assess: starting from a proposed list of stops, which ones should be introduced? To deal with this issue we have built a multi-criteria approach associating transport and urban considerations. The criteria include accessibility measurements, impact of each stop on the total travel time, catchment areas for population and 
jobs, existing urban functions in the neighbourhood of the stops, potential for urban development of housing, activities and equipment, potential for connection with other modes, and cost of construction.

The multi-criteria analysis is able to provide some clear information about the opportunity of introducing each stop. The analysis raises some questions concerning three out of the seven new stops, and provides some relevant information for the decision processes.

Keywords multi-criteria method $\cdot$ tram-train $\cdot$ TOD

\section{Introduction}

The Bahn.Ville project focuses on the relations between urban and regional development and the railway mode in France and in Germany. This project has been achieved through two successive phases [1,2], the first of them aimed at identifying the key elements of a rail oriented urban development. The scientific objectives where then to develop new knowledge about urban and rail dynamics.

The success of Transit Oriented Development (TOD) or rail oriented development depends on several factors $[3,4]$, among them the characteristics of the public transport system should not be neglected. TOD as a concept was initially developed by Calthorpe [5], and refers to a mixed and moderately dense urban development around transit stops with an objective to develop the use of transit, active modes and other alternatives to cars. Recent literature shows that TOD versus non-TOD development proposes a significantly lower car use, from 30 and 50 percent $[6,7]$. The current vitality of TOD as a domain of research in France and in the world is patent [8-12. For what concerns transport systems evaluation, TOD literature indicates the need for including more dimensions and criteria than those strictly related to transport. In line with these approaches, like for instance the node-place analysis of Bertolini and Spit, the aim of the current work is to introduce a transport system assessment method that considers the perspective of TOD, i.e. that encompasses altogether transport and urban issues.

As investigated in the first phase of the Bahn.Ville project [1] two key elements have to be taken into consideration in a rail oriented project:

- the quality of service level which must be above a minimum threshold ${ }^{1}$;

- the technical characteristics (such as acceleration and braking performances).

\footnotetext{
${ }^{1}$ This threshold depends on a set of factors including urban context, the differential of supply between major and secondary stops, and can be measured through the number of daily commute possibilities (about 10) of hourly frequencies (about 2 trains per hour in average).
}

Both aspects have an influence on the distance between stops and therefore on the urbanization potential in the surroundings of the line. In addition, the transport system has to be evaluated in the context of the whole public transport network with a focus on the intermodal connexions.

There are different kinds of regional railway transport systems which are more or less appropriate for TOD or rail oriented urban development according to the context. The new concepts such as so-called "tram-trains" or "interconnexion trams" [13] are sometimes difficult to compare to more classical solutions. There are several criteria such as the reduction of the number of intermodal connexions, the improvement of vehicles performance, the reduction of dwell time.

The second phase of the Bahn.Ville project [2] has consisted in testing the conditions of implementation of the principles identified in the first phase [1]. The scientific objectives turned to the development of new tools, instruments and procedures for implementation. The French case study is the 17 kilometres Saint-Étienne to Firminy railway line. This line has a railway service running modernised in 2007 with new rolling stock, electrification, refurbished stations and higher frequencies ${ }^{2}$.

In order to develop the public transport and to get the most out of the potential of the star-type railway network centred on Saint-Étienne, the municipality and the Region are studying the introduction of a tram-train system. On the Saint-Étienne Firminy corridor this project would mainly involve introducing many new intermediate stops. The problematic consists in selecting an optimal set of new stops considering the various dimensions of a city/transport project ${ }^{3}$.

\section{The tram-train project in the Saint-Étienne-Firminy corridor}

The project of a tram-train system in Saint-Étienne urban region originates in the reflection on future railway transport developed in the 2004 Local Transport Plan (PDU). A feasibility study was financed in 2006 by the intercommunality, the département and the region and realised by $\mathrm{TTK}^{4}$, in order to propose a new transport system

\footnotetext{
${ }^{2}$ In 200433 trains per day served the line, while in 2007 the figure was 70 trains each day.

${ }^{3}$ This study has been conducted inside the Bahn.Ville 2 project on the urban development oriented towards rail and intermodality on the Firminy to Saint-Étienne railway line corridor with contributions from Thomas Leysens and Sandra Bozzani-Franc (Université Paris Est LVMT Ifsttar), Anne-Marie Verdier and Catherine Araud Ruyant (EPURES urbanism agency).

${ }^{4}$ TTK is a transport consultant firm originating from Karlsruhe, the home of tram-train concept.
} 
taking advantage from the existing railway infrastructure star-form centred on Saint-Étienne.

The tram-train project consists in introducing 8 new stops served by a new tram-train type rolling stock while maintaining the existing regional railway supply on the existing stations. The following figure (fig. 1) shows the potential site for creating a new stop next to the centre of the commune of Fraisses on the single track section of the line ${ }^{5}$ and surrounded by typical density of secondary centres in the Saint-Étienne to Firminy corridor.

Before this contribution in the context of the Bahn.Ville project, the feasibility study of the tram-train identified the potential impact of the introduction of the proposed transport system on the territory of the Saint-Étienne to Firminy line. But local decision makers at agglomeration and region levels had the impression that too many stops for a relevant tram-train transport system had been proposed in this feasibility study. To deal with this issue, the Bahn.Ville team was asked to establish an order of priority of the proposed new stations, and eventually eliminate superfluous stops.

In a typical tram-train approach [14-16] as implemented in Karlsruhe [17], a new transport system is proposed with a specific rolling stock, intermediate between tramways and trains, operated on urban tram tracks as well as on existing conventional railway system. It makes it possible to design a transport system with long lines that is able to irrigate dense urban fabric and serve periurban centralities. The adaptation to both central and peripheral contexts, and the expectation of relatively low investment costs by reusing existing infrastructure, explain the interest for such systems in metropolitan contexts.

This kind of system provides no particular benefits in terms of accessibility in the urban dense fabric as compared to classical tramways. But in the peripheral contexts, the system permits to better irrigating and serving the territory through the addition of new stops on existing railway lines. In principle, according to Bouhet [18], this can be done without losing time on the overall journey by using intermediate rolling stock (between trains and trams) able to decelerate and accelerate faster than conventional heavier trains. Nevertheless an attention should be paid to the fact that tram-train systems sometimes have to coexist with classic heavy rail services, which leads to capacity and operations constraints, as would probably be the case on the Firminy-Saint-Étienne line.

As we can see, the tram-train approach combines urban considerations with functional characteristics of the transport system to provide new benefits in terms of

\footnotetext{
${ }^{5}$ As can be seen on figure 2, Fraisses is located at the eastern extremity of the line, beyond Firminy, where current traffic does not justify a doubling of the railway line.
}

accessibility, as compared to heavier systems. To deal with this issue we have built a multi-criteria approach associating transport and urban considerations. As opposed to a transport focused approaches of tram train assessment $[16,19]$ where key criteria are frequency, speed, patronage or cost, we want to combine the assessment of transport and urban dynamics following the indications of Naegeli et al. [15]; this is the reason of our choice of a multi-criteria analysis. The main criteria we will consider are interstation distance, travel times, accessibility gains, investment costs, urban profile of stations surroundings, urban densities, potential for urban development. This approach is applied on a set of given potential station locations.

\section{A multi-criteria approach for assessing the opportunity of new stops}

In a decision framework approach, the tram-train project involves several criteria belonging to the two distinct but interrelated fields of transport and urbanism. We will discuss now these different aspects and investigate how their analysis can help to take the decision.

A major issue consists in determining the distance between stations in the new transport system. To deal with this problem we have studied the layout of four existing tram-train lines in France and in Germany. The cases of Karlsruhe, Sarrebruck, Aulnay-Bondy and Mulhouse are compared with the present project.

As Table 1 shows, significant differences in the interstation distance can be found between studied situations. It ranges from 266 meters to more than 5,000 meters. From these figures it can be stated that tram-train systems do not come with a typical inter-station distance. This distance must be adapted to contexts. The analysis of contexts shows that interstation distances depends on two criteria, i.e. the urban fabric traversed by the lines and the type of rail infrastructure, as follows.

- On urban tram type system distances are generally short, around $4.50 \mathrm{~m}$ in average;

- On national railway system interstation are longer but also less regular; between $700 \mathrm{~m}$ and 2,000 meters;

- In urban fabric distance ranges between 450 and 700 meters in average.

From this analysis it can be stated that the Saint-Étienne to Firminy project is consistent with other comparable projects. Nevertheless, interstation distances can be seen as relatively shorter than other projects on national network and longer than other projects in urban fabric.

Directly related to the spatial distribution of stations the issue of total travel time along the line is a key aspect. The 


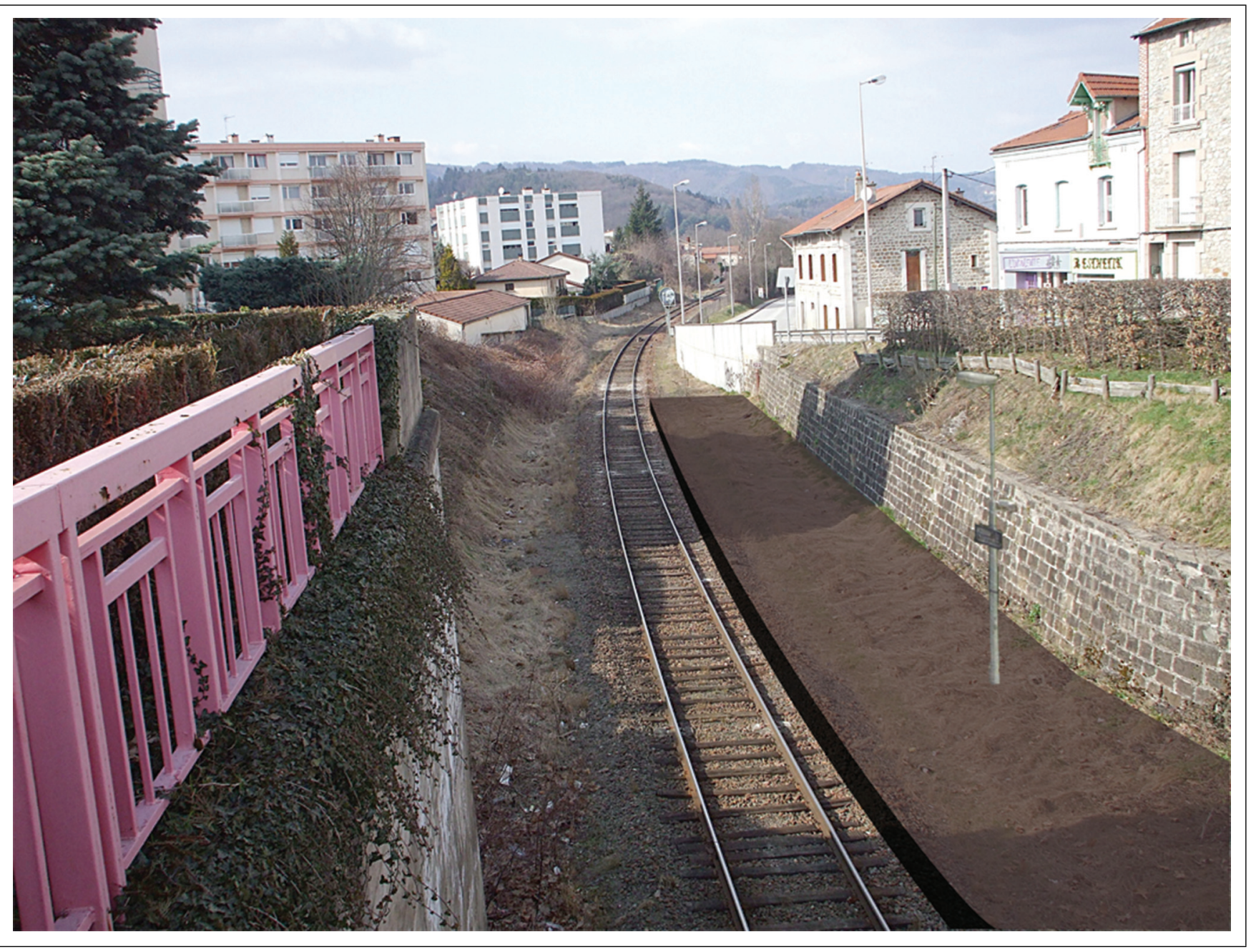

Fig.1 Location of the projected tram-train new stop in Fraisses-Ville (Photo S Bozzani-Franc 2009) with a proposed platform on the right

\begin{tabular}{|c|c|c|c|c|c|}
\hline & Karlsruhe & Sarrebruck & Aulnay-Bondy & Mulhouse & $\begin{array}{l}\text { Saint-Étienne } \\
\text { tram-train project }\end{array}$ \\
\hline Line & $\begin{array}{l}\text { Karlsruhe- } \\
\text { Bretten }\end{array}$ & $\begin{array}{l}\text { Riegelsberg } \\
\text { Süd-Sarreguemines }\end{array}$ & Aulnay-Bondy & $\begin{array}{l}\text { Mulhouse } \\
\text { Gare-Thann }\end{array}$ & $\begin{array}{l}\text { Fraisses-Firminy- } \\
\text { Saint-Étienne } \\
\text { (Chateaucreux) }\end{array}$ \\
\hline Length of line & $35.4 \mathrm{~km}$ & $26 \mathrm{~km}$ & $7.7 \mathrm{~km}$ & $22.4 \mathrm{~km}$ & $16.9 \mathrm{~km}$ \\
\hline Number of stops & 30 & 23 & 11 & 18 & 15 \\
\hline Distance between stops & $\begin{array}{l}\text { Min: } 266 \mathrm{~m} \\
\text { Max: 5,280 m } \\
\text { Avr: 1,221 m }\end{array}$ & $\begin{array}{l}\text { Min: } 270 \mathrm{~s} \mathrm{~m} \\
\text { Max: } 2,930 \mathrm{~m} \\
\text { Avr: } 1,183 \mathrm{~m}\end{array}$ & $\begin{array}{l}\text { Min: } 550 \mathrm{~m} \\
\text { Max: } 1,380 \mathrm{~m} \\
\text { Avr: } 772 \mathrm{~m}\end{array}$ & $\begin{array}{l}\text { Min: } 298 \mathrm{~m} \\
\text { Max: } 4,690 \mathrm{~m} \\
\text { Avr: } 1,316 \mathrm{~m}\end{array}$ & $\begin{array}{l}\text { Min: } 576 \mathrm{~m} \\
\text { Max: } 3,150 \mathrm{~m} \\
\text { Avr: } 1,209 \mathrm{~m}\end{array}$ \\
\hline
\end{tabular}

Necplus 
Table 2 comparing inter-station time-distances on five tram-train lines

\begin{tabular}{|c|c|c|c|c|}
\hline & $\begin{array}{l}\text { Observed time } \\
\text { (from timetables) }\end{array}$ & $\begin{array}{l}\text { Simulated - } \\
\text { existing (TER) } \\
\text { rolling stock - } \\
\text { existing stops }\end{array}$ & $\begin{array}{l}\text { Simulated - } \\
\text { tram-train rolling } \\
\text { stock - news stops }\end{array}$ & $\begin{array}{l}\text { Simulated - } \\
\text { existing (TER) } \\
\text { rolling stock - new } \\
\text { stops }\end{array}$ \\
\hline Running time & & $17 \mathrm{~min}$ & $18 \mathrm{~min}$ & $22 \mathrm{~min}$ \\
\hline Stopping time* & & $6 \min$ & $7 \mathrm{~min}$ & $13 \mathrm{~min}$ \\
\hline Total time & $26 \mathrm{~min}$ & $23 \mathrm{~min}$ & $25 \mathrm{~min}$ & $35 \mathrm{~min}$ \\
\hline
\end{tabular}

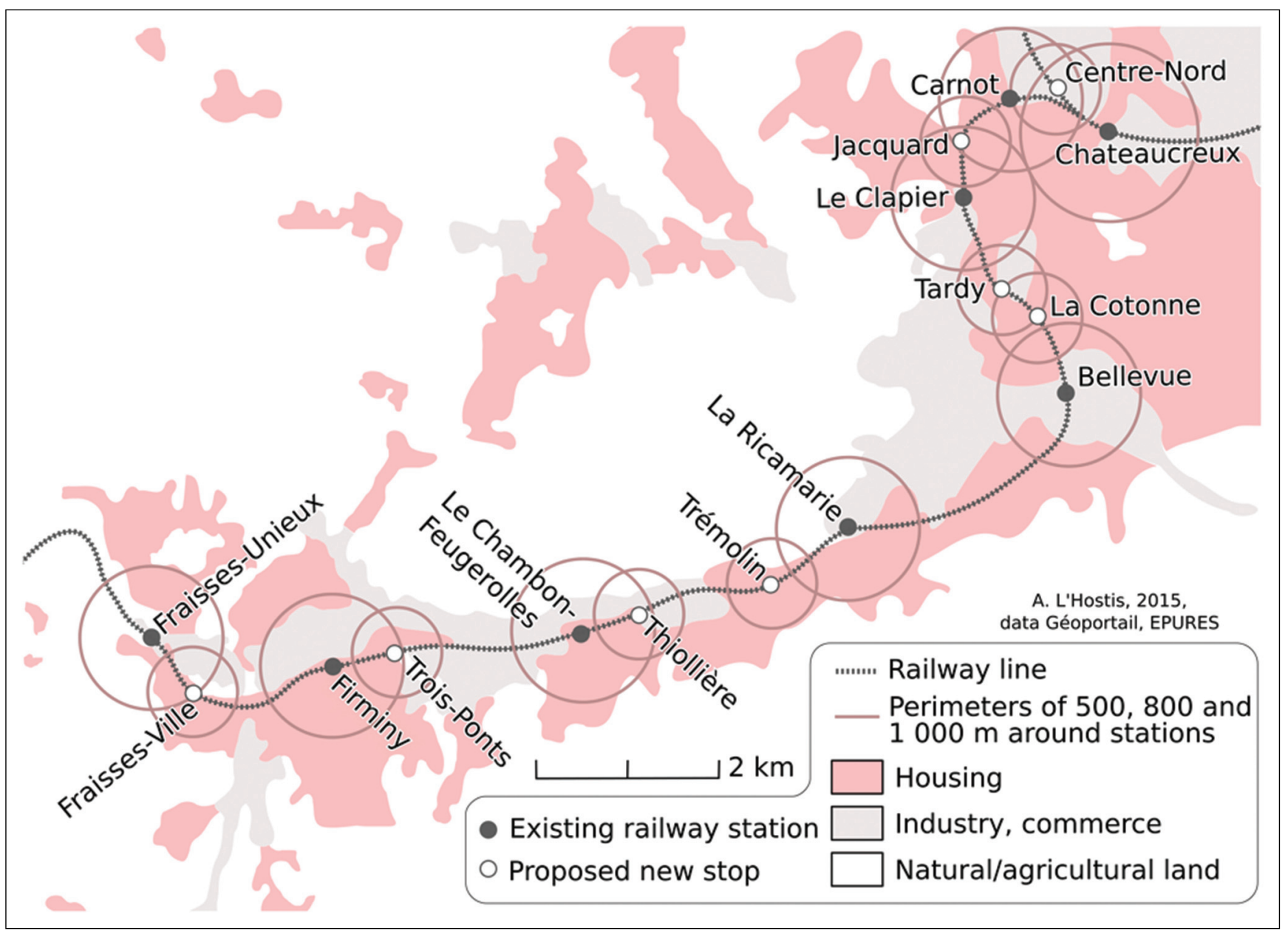

Fig.2 Catchment areas of existing and projected new stops on the Fraisses to Saint-Étienne railway line (EPURES)

tram-train approach states that new stops can be introduced without lengthening the global travel time by using a lighter rolling stock. This criterion has been extensively covered in an article by Vulturescu et al. (Vulturescu, L'Hostis, \& Soulas 2011). The method has consisted in simulating two types of rolling stock, existing and projected, and two situations of infrastructure, with and without the new stops (Table 2).
From this work it appears that the existing heavy rolling stock does not make it possible to maintain the total travel times by adding seven stops to the seven existing ones. On the contrary the use of tram-train type rolling stock allows to produce total travel times that are similar to those realised or simulated with the existing heavier rolling stock. This result is consistent with the literature on this subject $[14,15$, $18,20]$. 
The next criterion to be studied is the catchment areas of new stations. The map (Fig. 2) shows existing and projected new stops with their respective catchment areas. As discussed in the Bahn.Ville project, different catchment perimeters have been considered [2] according to the level of influence of stations.

- 1,000 $\mathrm{m}$ for a long distance railway station (1 station)

- $800 \mathrm{~m}$ for a regional rail station (7 stations)

- $500 \mathrm{~m}$ for tram-train stops (5 stations) ${ }^{6}$

The choice of radius was made according to existing literature $[8,21,22]$. The basic principles are pedestrian accessibility radius combined with consideration of hierarchical level of stations.

As can be seen on the map, a considerable amount of space is covered by two or more stations. The overlap is strong as all the new stops share some space of influence with existing stations. Nevertheless the new stops allow for a better coverage of urban fabric by the railway line in the tram-train configuration. By means of Geographic Information System it is possible to determine the number of population and jobs covered by transit stops ${ }^{7}$. It has been computed that the proposed tram-train system would allow to access to $50 \%$ of the population and to $60 \%$ of the jobs of the urban corridor, understood as the territory of the communes served by the line, while the existing system serves approximately $37 \%$ of the population and $51 \%$ of the jobs. Computations have been realised by EPURES urbanism agency based on census data for population and jobs and on given radius ${ }^{8}$. Overlaps between neighbouring stations have been dealt with in the GIS. Beside the broad view, the analysis is used to feed into the multi-criteria analysis exposed below.

\section{Results of the multi-criteria analysis}

The method developed consists in combining transport related and urban related criteria in order to draw the large picture and help to choose the set of new stops. The criteria developed in the approach aim at capturing the major issues involved in the choice of a set of stations in an existing urban context:

\footnotetext{
${ }^{6}$ The new tram-train stops would not allow for stops of existing regional trains.

${ }^{7}$ Population data comes from general census at IRIS level. Jobs data come from the geocoded Sirene firms database.

${ }^{8}$ More sophisticated accessibility measurement like time-space envelopes were not used in this computation, despite being more accurate measurement. Fixed radii were considered as sufficient for the purpose of the current analysis.
}

- accessibility gains by the new transport system;

- additional travel time due to the insertion at a new stop;

- investment cost of the stop and its accesses by all transport means;

- constraints for the urban design of stop areas;

- urban profile of stop area;

- potential for urban development, densification or new equipment.

All these criteria are detailed in Table 3 for the 14 existing and new stations in the Saint-Étienne-Firminy tram-train project $^{9}$, providing guidance on the choice of an appropriate set of stations and stops to be integrated. Additionally, a newly proposed intermediate new stop between La Cotonne and Tardy, which could serve as an alternative to those two stops proposed in the feasibility study, is detailed.

Accessibility criteria are quantitative measurement while the other urban quality criteria results from qualitative analysis conducted by professionals of Saint-Étienne agglomeration urbanism agency EPURES who have a comprehensive view on this territory. In order to assess the potential for urban development, the method considers underutilised urban space, with vacant land and land likely to be vacant, but also the potential densification by urban renewal. Developed in the context of a research-action project, this method uses local expertise to populate indicators; this is certainly an advantage for the relevance of the assessment on the present case. Nevertheless, if we consider the generalisation in other contexts, using local expertise certainly adds complexity. The alternative of a GIS based measurement of urban potential could usefully be developed instead.

Among the criteria the population and jobs accessible have been computed as population present in the attraction areas centred on the stops as shown on figure 2. Between parenthesis are detailed the figures of newly served population: this encompasses the residents and jobs that were not previously served by the existing stations, in order to reveal the possible duplicate service of the new stops. The tram train project allows to serve 10,450 new inhabitants and 3,650 new jobs.

The urban potential of each stop is considered through the study of the existing urban functions, housing, centrality, major equipment and activity. In addition a prospective approach shows the potential for urban renewal including densification, and for new developments located whether on free land or on brown field.

\footnotetext{
${ }^{9}$ Two stations are not included in the analysis: Centre-Nord which is located on the northern branch of the project, and Chateaucreux which has a size and an influence radius much larger than the other stations and hence belongs to a different category.
} 


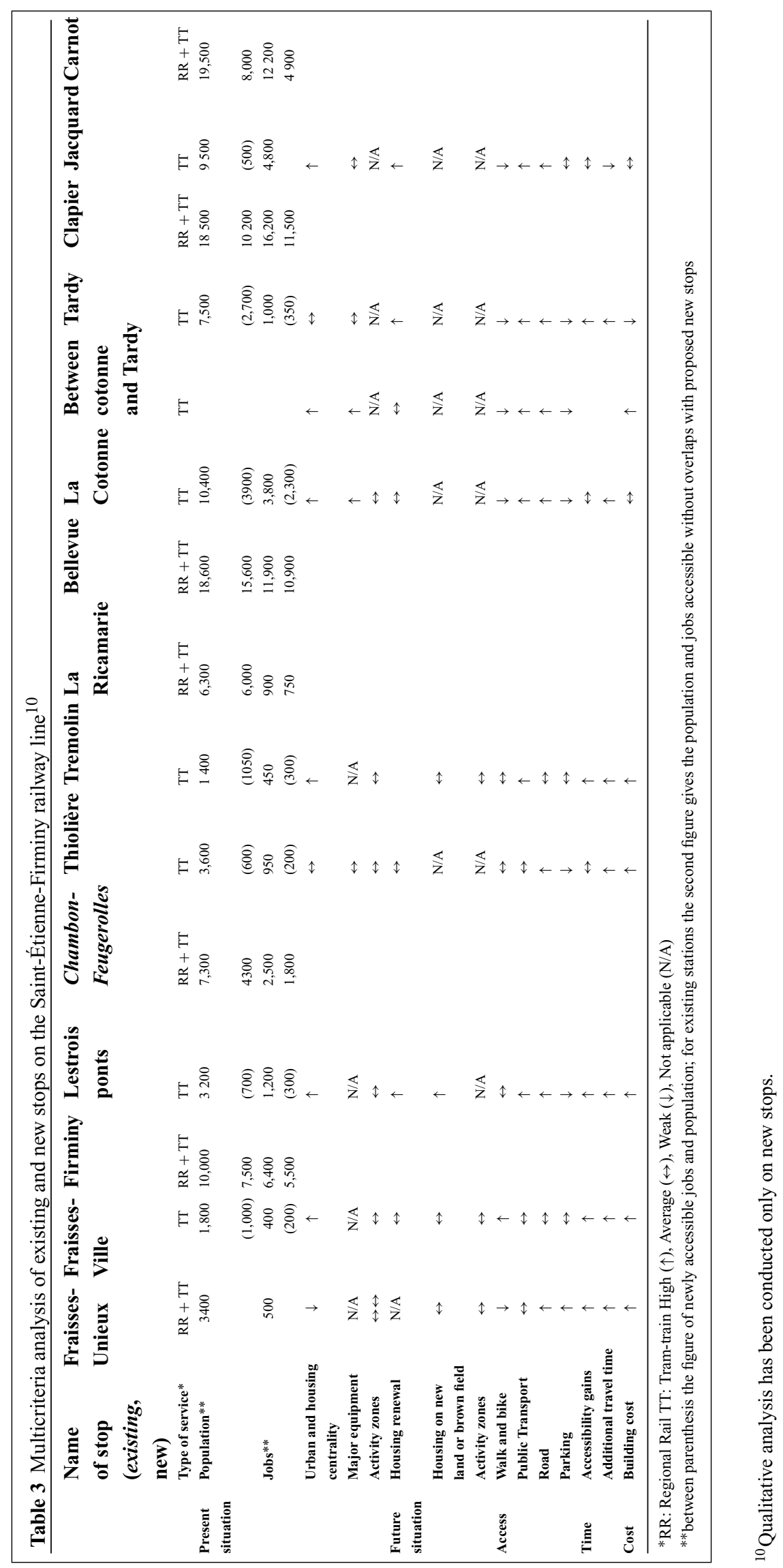

Necplus 
The conditions of access to the new stop are studied by analysing the conditions of access to the various modes. It includes pedestrian and bicycle access and public transport. The access by car is analysed through the connection to the street system and the presence of parking lots.

The additional travel time study is developed more thoroughly by Vulturescu et al. [23]. This approach simulates the functioning of the railway line considering the characteristics of the infrastructure and of the vehicles envisaged, in the context of a mixed usage of tram-trains and regional trains. The addition of each stop is simulated individually in order to judge the impact of its introduction or suppression in the project. From this analysis it appears that only one stop, Jacquard, has a negative significant impact on the total travel times because it is located too close to the existing stops and do not allow for the vehicle to reach the maximum permitted speed.

Building cost is assessed by the expertise of EPURES urbanists. Among the stations, Tardy has a high building cost because of the need to adapt the street design.

The tram train line that we study serves a densely populated urbanised of about 55,000 inhabitants valley surrounded by an extended agricultural and natural landscape and extending in the periphery of Saint-Étienne agglomeration (180,000 inhabitants). Between Saint-Étienne and Fraisses several types of urban centres can be seen: regional subcenter like Firminy or local urban pole like ChambonFeugerolles or Fraisses. Relatively dynamic commerce and retail coexists with declining or transforming industrial activities, while housing density varies considerably. Consequently, at the station area level, as the table shows, a wide variety of urban context and urban development potential can be observed. Dense urban fabric can be found around Les-Trois-Ponts or Jacquard for instance, while urban development potential is observed in Fraisses or Trémolin. Major equipment can be found close to La-Cotonne with Jean-Monnet University. Dominant housing function in Jacquard contrasts with more mixed urban of most other stations areas like for instance Les-Trois-Ponts or Trémolin.

The joint analysis of the criteria reveals some key issues for the stations. Three new stops present a clear opportunity from both urban and transport point of views, namely Fraisses, Les-Trois-Ponts and Trémolin. One of the new stops could be implemented at another location: La-Cotonne could be located further East, between La-Cotonne and Tardy, with much lower building cost and roughly the same urban configuration, even if accessibility impacts have not been measured. Two stops are raising some difficulties: Thiolière near Chambon-Feugerolles and Jacquard because they do not serve a significant number of population or jobs not covered by existing stations. The Tardy station seems very expensive to build despite some urban potential. Finally the existing Fraisses station could foster a park and ride facility to supplement the Firminy station already playing this role.
Finally it is worth mentioning that the methodology and the results were presented to and discussed with Bahn.Ville 2 project stakeholders including regional and intercommunal partners. These exchanges confirmed the indications of the analysis: it has been admitted that alternative scenarios modifying the set of stations initially proposed could improve the project, reduce costs, increase the reliability of the system without significantly reducing accessibility benefits.

\section{Conclusion}

Introducing a new transport system in an existing urban area is a complex question that involves several dimensions in both domains of transport an urbanism. In this paper we have developed a multi-criteria approach to help the decision process concerning the set of new stops to be introduced. The criteria include accessibility measurements, impact of each stop on the total travel time, catchment areas for population and jobs, existing urban functions in the surroundings of the stops, potential for urban development of housing, activities and equipment, potential for connection with other modes, and cost of construction. With each criterion measured and ranked in a table, this approach can build a set of analysis of each stop concerning its introduction.

Out of the proposed new stops three are raising questions. The Tardy new stop is characterised by high realisation costs with no significant potential for urban development. The opportunity of two other new stations can be discussed because they overlap with existing catchment areas by railway stations. Their introduction would essentially improve the transport condition of local users but is likely to provide a limited urban impact.

Several limitations and difficulties have been dealt with in this contribution. The assessment does not consider traffic potential and other elements of a complete transport project analysis that was conducted in the previous feasibility study and hence excluded to avoid redundancies. No method to reduce the inherent complexity of multi-criteria analysis have been developed in this study; rather our method demands that the decision makers tackle the complexity of the issue. We have elaborated expert conclusions based on multiple and sometimes conflicting criteria. Finally, addition, the postponement of the tram-train project in Saint-Étienne does not allow to assess if the results of the analysis and the recommendations will be implemented.

The relevance of the criterion and the quality of the information they provide indicate that the method developed for the Saint-Étienne to Firminy case study could be adapted on other railway lines with similar problematic. 
Remerciements This research has been conducted in the Bahn.Ville 2 research-action project funded by the French ministry of ecology and sustainable development, the Rhône-Alpes region, the agglomeration community of Saint-Étienne, EPORA and EPA Saint-Étienne.

\section{References}

1. Pretsch, H, Spieshöfer, A, Puccio, B, Soulas, C, Leclercq, $\mathrm{R}$, Bentayou, G (2005) Enseignements du projet Bahn.Ville, Inrets/Certu, Arcueil/Lyon: 168.

2. L'Hostis, A, Alexandre, E, Appert, M, Araud-Ruyant, C, Basty, M, Biau, G, Bozzani-Franc, S, Boutantin, G, Constantin, C, Coralli, M, Durousset, M.-J, Fradier, C, Gabion, C, Leysens, T, Mermoud, F, Olny, X, Perrin, E, Robert, J, Simand, N, Stransky, V, Soulas, C, Verdier, A.-M, Vulturescu, B (2009) Concevoir la ville à partir des gares, Rapport final du Projet Bahn.Ville 2 sur un urbanisme orienté vers le rail, Predit/Deufrako: 84.

3. Cervero, R (1998) The Transit Metropolis, a Global Inquiry, Island Press, Washington.

4. California Department of Transportation Transit-Oriented Development Study: Factors for Success in California.

5. Calthorpe, P (1993) The next American metropolis: Ecology, community, and the American dream, Princeton Architectural Press.

6. Arrington, G. B, Cervero, R (2008) Effects of TOD on Housing, Parking, and Travel, TCRP Report.

7. Faghri, A, Venigalla, M (2013) Measuring Travel Behavior and Transit Trip Generation Characteristics of Transit-Oriented Developments. Transportation Research Record: Journal of the Transportation Research Board 2397: 72-79.

8. Bertolini, L, Spit, T (1998) Cities on rails: the redevelopment of railway station areas, E \& FN Spon, London.

9. Leysens, T (2011) Reconfiguration des réseaux de transport et renouveau urbain: l'enjeu d'un urbanisme orienté vers le rail, Géographie et Aménagement, Lille 1.

10. Brès, A (2014) Train stations in areas of low density and scattered urbanisation: towards a specific form of rail oriented development, Town Planning Review 85: 261-272.
11. Feudo, FL (2014) How to Build an Alternative to Sprawl and Auto-centric Development Model through a TOD Scenario for the North-Pas-de-Calais Region? Lessons from an Integrated Transportation-land Use Modelling, Transportation Research Procedia 4: 154-177.

12. Grillet-Aubert, A, Grosjean, B, Leloutre, G, Pucci, P, Bazaud, C, Bowie, K (2015) La desserte ferroviaire des territoires périurbains: Construire la ville autour des gares, Recherches, Paris.

13. Soulas, C (2001) Evolution of guided transport systems for urban and suburban applications, WCRR World Congress on Railway Research: 11

14. Novales, M, Orro, A, Bugarin, M (2002) The tram-train: State of the art. Proceedings of the Institution of Mechanical Engineers, Part F: Journal of Rail and Rapid Transit 216: 1-13.

15. Naegeli, L, Weidmann, U, Nash, A (2012) Checklist for Successful Application of Tram-Train Systems in Europe. Transportation Research Record: Journal of the Transportation Research Board 2275: 39-48.

16. Tribout, J, Le Blan, C (2015) Le tram-train: cheminement du concept initial aux réalisations. Revue générale des chemins de fer: $7-22$.

17. Beaucire, F (2000) Un réseau et ses territoires: le tram-train d'interconnexion de Karlsruhe (Allemagne), Flux 16: 41-45.

18. Bouhet, O (2006) Transports publics et structuration de l'espace périurbain : méthode d'aide à la décision pour l'implantation d'un tram-train. Exemple d'application de Grenoble à Crolles (moyenne vallée du Grésivaudan), Université Joseph-FourierGrenoble I.

19. Forthoffer, J (2012) Périurbain et tram-train: enjeux, projets et réalisations. Revue Géographique de l'Est 52.

20. Novales, M, Orro, A, Bugarin, M (2002) Tram-Train: New Public Transport System. Transportation Research Record: Journal of the Transportation Research Board 1793: 80-90.

21. Certu (1997) Évaluation des transports en commun en site propre: indicateurs transport pour l'analyse et le suivi des opérations, Certu, Lyon.

22. Bertolini, L, Dijst, M (2003) Mobility environments and network cities. Journal of Urban Design 8: 27-43.

23. Vulturescu, B, L'Hostis, A, Soulas, C (2011) Simulation des temps de parcours du transport ferroviaire régional du bassin de vie stéphanois dans le cadre du projet Bahn.Ville. Recherche Transports Sécurité: 1-15. 
